\title{
Literasi Informasi Pustakawan: Studi Kasus di Universitas Padjadjaran
}

\author{
Sukaesih dan Asep Saeful Rohman \\ Departemen Ilmu Informasi dan Perpustakaan Fikom Unpad \\ Jl. Raya Bandung-Sumedang Km. 21 Jatinangor 45363 \\ Email: sukaesihcicih09@yahoo.co.id
}

\begin{abstract}
ABSTRAK - Penelitian ini bertujuan untuk mengetahui sejauhmana literasi informasi para pustakawan khususnya di lingkungan Universitas Padjadjaran. Penelitian ini mencakup kompetensi literasi informasi para pustakawan di Universitas Padjadjaran dan bagaimana penerapannya di perpustakaan. Metode yang digunakan dalam penelitian ini adalah studi kasus. Pengolahan data dilakukan dengan menyajikan deskripsi hasil wawancara, pengamatan dan observasi secara naratif. Populasi dalam penelitian ini adalah para pustakawan dan tenaga perpustakaan lainnya yang ada di lingkungan Universitas Padjadjaran. Penentuan sampel dilakukan secara purposive sampling yaitu hanya pada sejumlah staf perpustakaan yang telah menjadi fungsional pustakawan di Universitas Padjadjaran. Hasil penelitian menunjukkan bahwa kompetensi literasi informasi pustakawan di Universitas Padjadjaran sudah baik. Mereka sudah dapat menentukan kebutuhan informasinya dan memahami kebutuhan informasi pengguna di perpustakaannya. Kemampuan penelusuran informasi masih dilakukan secara sederhana. Mereka belum menggunakan teknik penelusuran yang efektif dan efisien baik untuk kepentingan dirinya maupun pada saat melayani pengguna. Pengetahuan tentang search engine juga masih kurang memadai sehingga dapat menghambat proses penelusuran informasi. Informasi yang mereka dapatkan digunakan dan diterapkan untuk peningkatan kompetensi dan profesionalisme kerja mereka sebagai pustakawan. Pustakawan di Universitas Padjadjaran menerapkan kemampuannya tersebut dalam melayani kebutuhan informasi pengguna. Mereka menyebarluaskan kemampuannya tersebut kepada orang lain terutama pengguna. Harapannya adalah agar pengguna dan orang lain mampu memanfaatkannya untuk dapat mengatasi setiap permasalahan yang dihadapi di lingkungan akademik dan dapat digunakan dalam kegiatan belajar sepanjang hayat.
\end{abstract}

Kata Kunci: Literasi Informasi, Pustakawan, Perpustakaan Perguruan Tinggi, Belajar Sepanjang Hayat, Teknologi Informasi.

ABSTRACT - This study aims to determine the extent of the information literacy librarians, especially in the environment of Padjadjaran University. This research involves the extent of the information literacy competency librarian at the University of Padjadjaran and how its application in the library. The method used in this research is a case study. Data processing is done by presenting a description of the results of interviews, observation and narrative observations. Population in this study are librarians and other library workers in the area of Padjadjaran University. Determination of the sample is purposive sampling performed only on the number of library staff who had become a librarian at the University of Padjadjaran. The results show that the competency of information literacy librarian at the University of Padjadjaran was good. They are able to determine information needs and understand the information needs of library users. The ability of information retrieval is still performed in a simple. They do not use effective search techniques and efficient both for the benefit of himself and at the time of serving the user. Knowledge of search engines is also still inadequate so as to inhibit the process of information search. The information they get is used and applied to increase the competence and professionalism of their work as a librarian. Librarians at the University of Padjadjaran apply these skills in serving the information needs of users. They spread their ability to others, especially the user. They hope users and others can use them to overcome any problems faced in the academic environment and can be used in lifelong learning activities.

Keywords: Information Literacy, Librarian, Higher Education Library, Life Long Learning, Information Technology.

\section{PENDAHULUAN}

\section{Latar Belakang}

Salah satu tugas pustakawan adalah membimbing pengguna perpustakaan untuk dapat lebih efektif dan efisien dalam mencari informasi yang mereka butuhkan. Kita mengenal berbagai macam istilah yang menggambarkan tugas pustakawan tersebut seperti pendidikan pengguna (user education), bimbingan pengguna, orientasi perpustakaan dan lain sebagainya. Tujuan dari semua itu jelas yaitu agar pengguna dapat dengan mudah dan cepat mendapat informasi atau bahan 
pustaka yang dicari olehnya. Bagi perpustakaan perguruan tinggi, hal semacam ini seharusnya menjadi sesuatu yang wajib untuk diikuti oleh setiap mahasiswa baru. Meskipun dalam memanfaatkan perpustakaan sudah sering mereka lakukan semenjak duduk di bangku sekolah, namun bimbingan/pendidikan pengguna tetap diperlukan mengingat antara sistem perpustakaan sekolah dan perguruan tinggi berbeda dalam berbagai hal. Oleh karena itu, bimbingan/pendidikan pengguna ini mutlak harus dilakukan, terutama kepada mahasiswa baru.

Seiring dengan perkembangan ilmu pengetahuan dan teknologi, ragam informasi dan pengetahuan juga turut berkembang pesat. Informasi hampir setiap saat diproduksi oleh setiap orang dan lembaga. Perkembangan teknologi informasi dan komunikasi juga turut memudahkan setiap orang untuk menghasilkan informasi. Hal tersebut yang mengakibatkan terjadinya ledakan informasi dan masalah dalam mengelolanya. Termasuk dalam hal proses penemuan kembali pada saat diperlukan. Masalah yang sama juga dialami oleh hampir setiap perpustakaan. Sehingga sistem pengelolaan perpustakaan kini banyak memanfaatkan teknologi informasi dan komunikasi untuk mengatasinya. Karena itu semakin banyak pula perpustakaan yang memiliki informasi yang lebih beragam dengan sistem pengelolaan yang semakin baik.

Perkembangan dalam sistem pengelolaan perpustakaan saat ini membuat penggunaan perpustakaan menjadi tidak sesederhana seperti sebelumnya. Pengguna dituntut untuk lebih memahami keragaman informasi, cara yang tepat dan mudah dalam mencari/menelusurnya, dan menggunakan berbagai perangkat sistem layanan informasi tersebut. Pengguna perpustakaan diharapkan tidak lagi kesulitan dalam mendapatkan informasi dan mengetahui betul apa yang ia butuhkan. Mereka juga harus tahu kemana serta bagaimana cara untuk memperolehnya, mengevaluasinya, menggunakannya, dan menyebarkannya dengan benar. Ketika kondisi pengguna sudah sampai semacam itu dalam istilah Bahasa Inggris disebut sebagai pengguna yang sudah information literate.

Berdasarkan kesepakatan yang diambil pada World Summit on the Information Society (WSIS) di Geneva pada tahun 2003 dan di Tunisia pada tahun 2005, bahwa setiap orang dapat mencipta, mengakses, menggunakan dan berbagi/ membagikan informasi dan pengetahuan. Sebagai konsekuensinya bahwa setiap orang saat ini harus dapat menghadapi dan menguasai informasi dengan benar.

Di negara maju seperti di negara-negara Eropa, Amerika dan Australia, sudah lama berkembang suatu konsep tentang literasi informasi. Bahkan banyak negara dan lembaga yang menyepakati suatu tingkat kemampuan atau kompetensi tertentu untuk mewujudkan konsep itu. Dalam pengembangan dan pelaksanaan konsep itulah peran pustakawan sangat dibutuhkan. Mengapa? Karena di perpustakaanlah (dalam hal ini perpustakaan dalam arti yang luas) tempat terjadinya akumulasi sumber dan aktifitas informasi, belajar dan pengetahuan.

Kembali pada masalah di atas, bahwa di perpustakaan perguruan tinggi mutlak diperlukan kegiatan bimbingan/pendidikan pada penggunanya terutama pada setiap mahasiswa baru. Sesuai dengan bahasan di atas juga disebutkan bahwa setiap pengguna (mahasiswa) sudah seharusnya dapat menjadi seorang yang information literate agar ia dapat menjalani tugas dan aktifitasnya dengan dukungan dan dasar penggunaan informasi yang tepat. Diharapkan pula setiap masalah yang ia hadapi selama mengikuti aktifitas perkuliahan dan belajarnya dengan baik dan lancar. Tugas dan tanggung jawab untuk itu jelas harus dilakukan oleh para pustakawannya. Karena pustakawanlah yang tahu dan seharusnya mengetahui konsep literasi informasi maupun bimbingan/pendidikan pengguna lainnya.

Di Universitas Padjadjaran, terdapat beragam perpustakaan baik di tingkat pusat (di Unpad namanya CISRAL/UPT Perpustakaan Pusat) maupun tingkat fakultas dan jurusan. Pada setiap perpustakaan ada yang sudah memiliki staf pustakawan dan ada juga yang belum. Namun terlepas apakah perpustakaan-perpustakaan di lingkungan Unpad tersebut sudah memiliki staf pustakawan maupun belum, atau berapa jumlah pustakawan yang ada di Unpad, melalui penelitian ini peneliti ingin meneliti sejauhmana pustakawan di Unpad telah mengenal, mengetahui dan menerapkan konsep literasi informasi baik untuk kepentingan dirinya sendiri maupun untuk digunakan dalam melaksanakan tugasnya dalam melayani setiap penggunanya di perpustakaan. 


\section{PERUMUSAN MASALAH}

Berdasarkan paparan pada latar belakang di atas maka rumusan masalah dalam penelitian ini adalah pada kemampuan/kompetensi literasi informasi Pustakawan di Universitas Padjadjaran dalam menunjang profesionalismenya.

Dari rumusan di atas kiranya dapat diidentifikasi masalah dalam penelitian ini secara lebih rinci yaitu sebagai berikut:

1. Bagaimana kemampuan literasi informasi para pustakawan di lingkungan Unpad?

2. Bagaimana mereka menerapkan kemampuan

literasi informasi tersebut di dalam pelayanan perpustakaan di lingkungan Unpad?

\section{TINJAUAN TEORITIS}

\section{Konsep dan Definisi Literasi Informasi}

Istilah literasi informasi pertama kali dikemukakan pada tahun 1974 oleh Paul Zurkowsky, salah seorang presiden pada Information Industry Association of United States, dalam proposal yang diajukannya kepada National Commision on Libraries and Information Science. Pada proposalnya itu ia menyebutkan bahwa salah satu yang harus dicapai dalam program nasional adalah literasi informasi secara universal. Zurkowsky menyatakan bahwa seseorang yang terlatih dalam menggunakan dan memanfaatkan sumber-sumber informasi dalam menyelesaikan tugas dan masalah mereka disebut sebagai orang yang melek informasi atau information literate person. Mengapa demikian, karena menurutnya bahwa seseorang tersebut telah mempelajari beragam teknik dalam menggunakan informasi dengan baik serta memiliki keterampilan dalam menggunakan beragam alat akses dan sumber informasi.

The UK's Chartered Institute of Library and Information Professionals (CILIP) membuat satu definisi literasi informasi pada tahun 2005 bahwa lietrasi informasi adalah kemampuan untuk mengetahui kapan dan kenapa kita membutuhkan informasi, mengetahui dimana kita dapat menemukan dan bagaimana mengevaluasinya, serta dapat menggunakan dan mengkomunikasikan sesuai etika (Amstrong, 2005).

Menurut ALA, literasi informasi adalah serangkaian kemampuan yang dibutuhkan seseorang untuk menyadari kapan informasi dibutuhkan dan memiliki kemampuan untuk menemukan, mengevaluasi dan menggunakan informasi yang dibutuhkan secara efektif. Namun begitu, dari berbagai definisi yang ada mengenai literasi informasi semuanya cenderung memiliki kesamaan.

\section{Literasi Informasi}

Salah satu pedoman literasi informasi yang telah ada yaitu pedoman yang dikeluarkan oleh International Federation of Library Associations and Institution (IFLA). Pedoman IFLA Information Literacy Standards terdiri dari tiga komponen dasar, yaitu access, evaluation, use dalam konteks informasi. Tiga komponen inti ini merupakan komponen dasar yang banyak ditemukan di beberapa standar yang dibuat oleh beberapa standar yang dibuat oleh berbagai asosiasi perpustakaan di dunia seperti American Asociation of School Librarian (AASL), American College Research Librarian (AASL), American College Research Libraries (ACRL), Standing Conference of National and University Libraries (SCONUL), dan The Australian and New Zealand Institute for Information Literacy.

Berdasarkan pemaparan di atas, kiranya dapat disimpulkan bahwa literasi informasi terdiri dari empat komponen dasar dalam konteks informasi yaitu determine of information needs, access of information, dan use of information.

1. Menentukan Kebutuhan Informasi

Langkah pertama yang harus dilakukan sebelum penelusuran informasi adalah mendefinisikan dan menentukan kebutuhan informasi. Menyadari kebutuhan informasi merupakan satu kepekaan terhadap informasi bahwa informasi dibutuhkan untuk menyelesaikan masalah baik di tempat kerja, memahami kebutuhan bermasyarakat, mengatasi masalah kesehatan serta menjalankan berlangsungnya kehidupan. Oleh karena itu, menyadari akan kebutuhan informasi merupakan komponen pertama dalam literasi informasi.

2. Mengakses dan Mengevaluasi Informasi

Keterampilan ini dibutuhkan untuk mencari informasi yang kondisinya bergantung pada konteks dimana seseorang tersebut melakukan penelusuran dan jenis sumber informasi yang dibutuhkan, misalnya perpustakaan atau 
internet. Seseorang yang dikatakan melek informasi adalah orang yang dapat mengakses informasi serta mampu mengevaluasi informasi yang diperolehnya tersebut secara efektif, efisien dan etis.

Literasi informasi berhubungan dengan kemampuan dalam menggunakan teknologi informasi akan tetapi dengan kompetensi dan cakupan yang berbeda. Meningkatnya kemampuan seseorang dalam menggunakan teknologi informasi akan mendukung kemampuan literasi informasi. Namun dalam hal ini, kemampuan literasi informasi lebih fokus pada isi, komunikasi, analisis, penelusuran dan evaluasi informasi. Bukan pada kemampuan dan pemahaman tentang teknologi komputer seperti aplikasi spesifik hardware dan software. Keahlian teknologi informasi dalam literasi informasi lebih kepada kemampuan intelektual daripada sekedar memahami fisik dan aplikasi komputer. Jadi, literasi informasi merupakan suatu kerangka intelektual untuk dapat memahami, menemukan, dan menggunakan informasi yang dapat didukung dengan kemampuan dalam menggunakan informasi yang dapat didukung dengan kemampuan dalam menggunakan teknologi informasi seperti komputer dan internet (ACRL).

3. Menyimpan dan Menemukan Kembali Informasi

Manusia harus dapat selalu menghargai betapa pentingnya menyimpan informasi dan menemukannya kembali ketika diperlukan. Seseorang yang melek informasi dalam hal ini juga adalah orang yang dapat menggunakan berbagai macam media untuk membawa informasi dengan memberikan suatu pengaruh yang baik, sehingga mereka dapat menemukan kembali dan memperbaharui ketika dibutuhkan.

Selain itu, mereka juga menyimpan semua informasi yang sudah didapatkan dengan mengklasifikasikan atau membuat satu sistem tersendiri yang memudahkan dalam melakukan temu kembali informasi.

4. Pemanfaatan Informasi secara Efektif dan sesuai Etika

Penggunaan informasi secara efektif meliputi kemampuan berfikir kritis dan dapat memecahkan masalah. Tujuan dari literasi informasi adalah untuk memungkinkan seseorang untuk menciptakan dan menggunakan pengetahuan sehingga pada akhirnya kembali dapat mewujudkan information literacy itu sendiri.

Menurut The Australian and New Zealand Institute for Information Literacy, seseorang dapat dikatakan melek informasi bila ia dapat mengaplikasikan informasi yang ia dapatkan untuk membuat satu konsep baru atau menciptakan suatu pemahaman baru dengan menggabungkan pengetahuan yang sudah ia miliki atau ia dapatkan sebelumnya. Hal ini dapat dilakukan dengan membandingkan dan menyatukannya untuk mengetahui nilai tambah, kontradiksi atau karakteristik dari informasi tersebut dan menemukan pemahaman baru secara efektif. Selain itu sebelum melakukan perbandingan, perlu diketahui juga apakah informasi sudah cukup memuaskan atau masih diperlukan verifikasi dengan menggunakan sumber informasi lain.

\section{Literasi Informasi dalam Menunjang Kompetensi Pustakawan dan Pelayanan Perpustakaan}

Keberadaan perpustakaan dan pustakawan jelas sangat diperlukan dalam masyarakat informasi saat ini. Perpustakaan merupakan salah satu jembatan bagi masyarakat untuk memperolah pengetahuan murah sehingga akan jauh dari kebodohan dan keterbelakangan. Peran perpustakaan dan pustakawannya, memungkinkan masyarakat dapat melakukan apa yang disebut dengan life long learning. Berbagai sumber informasi yang tersedia di perpustakaan tidak membatasi semua orang untuk terus belajar. Belajar tidak sebatas hanya melalui jalur formal saja. Sarana dan sumber informasi yang disediakan perpustakaan dapat dimanfaatkan 
untuk terus menggali ilmu pengetahuan. Hal ini tentu saja membutuhkan peran aktif pustakawan.

Kegiatan pokok di sebuah perpustakaan adalah mengumpulkan, melestarikan, dan menyajikan informasi untuk siap dipergunakan dan diberdayakan oleh penggunanya (Sutarno 2006, 1). Sehingga sesungguhnya bahwa peran perpustakaan tersebut dalam kehidupan di masyarakat jelas akan sangat luas. Kita juga menyadari bahwa saat ini informasi sudah merupakan sesuatu yang sangat penting. Setiap orang selalu membutuhkan informasi dalam kehidupan mereka. Kondisinya akan sangat berbeda antara masyarakat yang telah mampu dan yang masih kesulitan dalam mengakses dan mendapatkan informasi. Inilah sesungguhnya masalah yang banyak dialami oleh kebanyakan orang. Jadi bukan karena tidak adanya minat masyarakat untuk membaca dan memanfaatkan informasi tetapi karena sebagian besar masyarakat kita yang belum mendapatkan akses dan kesempatan untuk mendapatkan sumber-sumber informasi. Untuk itu, dengan adalnya perpustakaan maka berbagai masalah diatas akan dapat diminimalisasi.

Pemanfaatan perpustakaan sebagai pusat sumber belajar dengan memberikan kebebasan akases informasi perlu ditopang dengan keberadaan dan peran strategis dari para pustakawan. Pustakawan adalah sebuah profesi dengan kompetensi yang diperoleh melalui pendidikan dan atau pelatihan kepustakawanan serta mempunyai tugas dan tanggung jawab untuk melaksanakan pengelolaan dan pelayanan perpustakaan (UU No. 43 Tahun 2007).

Kompetensi yang harus dimiliki pustakawan sesuai dengan amanah dalam UU tersebut antara lain:

1. Pengelolaan informasi; pustakawan harus mampu mengelola informasi sehingga mudah ditemukan kembali ketika dibutuhkan oleh siapapun. Dalam hal ini diperlukan kemampuan mengumpulkan informasi sesuai kebutuhan pengguna, mampu mengolah, mengemas ulang informasi serta mampu menemukan kembali informasi yang dicari dan dibutuhkan oleh siapapun.

2. Literasi informasi; pustakawan harus mampu menyempaikan materi yang terkait dengan literasi informasi kepada pengguna. Oleh karena itu sebelumnya pustakawan harus telah memahami apa itu literasi informasi. Menurut Proboyekti (2008), literasi informasi adalah kemampuan untuk menjalani siklus belajar yang tak ada henti. Dengan kompetensi ini, pustakawan berkemampuan dan selalu bersemangat untuk terus belajar serta mampu melayani pengguna dan masyarakat secara prima dan penuh dedikasi.

3. Kemampuan interpersonal. Kemampuan ini berkaitan dengan kemampuan seseorang dalam berinteraksi dengan orang lain dan membangun hubungan baik dengan individu lain di masyarakat. Pustakawan dituntut untuk dapat menciptakan pola hubungan komunikasi yang efektif, menyenangkan, dan mudah dipahami. Sehingga pengguna tidak merasa segan dan justru malah merasa senang berhubungan dengan pustakawan.

4. Kemampuan intrapersonal. Kemampuan ini menuntut pustakawan untuk mempu memahami dirinya sendiri. Maksudnya bahwa pustakawan sebagai seorang profesional harus dapat bertanggung jawab terhadap dirinya, profesinya, lembaganya dan orang yang dilayaninya. Selain itu ia juga harus mampu mengenali perasaan dan mengendalikan emosinya. Memiliki sikap percaya diri dan berani mengambil keputusan. Serta mampu memotivasi dan selalu memperbaiki kekurangan yang masih dimilikinya.

\section{METODE PENELITIAN}

Penelitian ini merupakan penelitian dengan pendekatan kualitatif deskriptif berbentuk studi kasus yang bertujuan menggambarkan sifat-sifat suatu individu atau kelompok sasaran tertentu, atau untuk menentukan frekuensi adanya hubungan antara suatu gejala dengan gejala lain dalam suatu masyarakat (Koentjaraningrat 1993, 29). Melalui penelitian ini, kami sebagai peneliti menggambarkan mengenai literasi informasi para pustakawan di lingkungan Universitas Padjadjaran dalam melaksanakan aktifitas pelayanannya di 
Perpustakaan-Perpustakaan di Universitas Padjadjaran.

Terdapat alasan mengapa kami sebagai peneliti menggunakan metode kualitatif deskriptif ini yakni karena ingin melihat sebuah realitas atau fenomena yang ada sebagai sesuatu yang utuh/holistik, kompleks, dinamis, dan penuh makna (Sugiyono 2005, 1) di PerpustakaanPerpustakaan yang ada di lingkungan Universitas Padjadjaran. Dalam penelitian ini kami sebagai peneliti tidak akan melakukan penentuan hipotesa, tetapi lebih mengembangkan konsep tentang literasi informasi dan menghimpun data yang telah peneliti dapatkan di lapangan.

Studi kasus dalam penelitian ini sebagai suatu studi yang bersifat komprehensif, intens, rinci, dan mendalam serta lebih diarahkan sebagai upaya menelaah masalah-masalah atau fenomena yang bersifat kontemporer (Bungin 2007, 20) yaitu mengenai kompetensi literasi informasi para pustakawan di lingkungan Universitas Padjadjaran.

Sebagai objek dari penelitian ini adalah literasi informasi dalam menunjang kompetensi profesional para pustakawan, sedangkan subyek dalam penelitian ini sendiri adalah para fungsional pustakawan di lingkungan Universitas Padjadjaran.

Dalam rangka pemilihan sampel untuk dijadikan informan dalam penelitian ini adalah dengan menggunakan teknik sampling bertujuan (purposive sampling). Teknik ini digunakan karena beberapa keuntungan yaitu murah, cepat dan mudah serta relevan dengan tujuan dari penelitian ini. Karena itu, kami sebagai peneliti sebelumnya melakukan penentuan 4 (empat) kriteria dari sampel yang akan diambil yaitu:

1. Terdaftar sebagai pegawai tetap di Universitas Padjadjaran

2. Merupakan staf fungsional pustakawan

3. Aktif sebagai tenaga ahli dalam mengelola perpustakaan dan pelayanan pada pengguina perpustakaan di Universitas Padjadajaran

4. Bersedia berpartisipasi sebagai informan dalam penelitian ini

Kami sebagai peneliti menentukan kriteria tersebut dengan didasarkan pada pertimbangan bahwa kegiatan pelayanan dan pengelolaan perpustakaan, terutama di perguruan tinggi, merupakan wujud seseorang dalam mengekspresikan informasi yang dibutuhkan dan bentuk berliterasi informasi dalam wujud yang nyata.

Dari sekian banyak staf perpustakaan yang ada di lingkungan Universitas Padjadjaran, yang akan diwawancarai adalah sebanyak tujuh orang. Dalam penelitian kualitatif tentunya tidak ada ketentuan baku mengenai jumlah sampel minimal, karena dalam penelitian ini yang paling penting adalah kedalaman dan kekayaan data untuk dapat memahami masalah yang diteliti secara jelas yang menjadi tujuan utama penulisan kualitatif.

Pengumpulan data merupakan proses untuk mendapatkan data primer dalam penelitian yang bersangkutan. Dalam penelitian ini, terdapat beberapa tahap pengumpulan data diantaranya kajian pustaka, observasi dan wawancara.

Setelah data dari hasil penelitian diperoleh dengan menggunakan berbagai teknik pengumpulan data, tahap selanjutnya adalah mengolah data. Ada beberapa tahap yang sebaiknya dilakukan dalam suatu proses pengolahan data kualitatif yaitu: reduksi data, kategorisasi, analisis, interpretasi, penyajian data dan penarikan kesimpulan.

Pada intinya, analisis kualitatif adalah proses yang digunakan untuk mengurangi data yang diperoleh menjadi hal-hal yang perlu atau esensial saja. Proses ini tidak bersifat mekanis, tetapi melibatkan persepsi-persepsi terampil dari pihak peneliti. Data-data tersebut dianalisis secara sistematis agar dapat menjadi satu hasil penelitian yang representatif. Jika hal ini terlaksana dengan baik, maka hasil-hasil analisis akan memberikan suatu representatif yang sahih, yang valid mengenai ciri-ciri utama data tersebut.

\section{HASIL PENELITIAN}

Penelitian mengenai literasi informasi pustakawan ini dilakukan terhadap para pustakawan di lingkungan Universitas Padjadjaran mengingat Universitas Padjadjaran saat ini sedang mempersiapkan diri untuk menjadi Perguruan Tinggi Kelas Dunia (World Class University) dimana salah satu pendukung utama untuk mencapai itu adalah adanya kesiapan perpustakaan dan pustakawan dalam memberikan pelayanan informasi dan pengetahuan secara optimal.

\section{Menentukan Kebutuhan Informasi}

Kesadaran akan kebutuhan informasi merupakan suatu langkah awal dalam proses pemenuhan informasi seseorang. Sebelum 
seseorang tersebut menyadari akan kebutuhan informasi, ia harus terlebih dahulu mengetahui apa itu kebutuhan informasi. Untuk dapat mengetahui pemahaman mereka akan kebutuhan informasi, maka tentunya kita harus ajukan pertanyaan tentang apakah definisi dari kebutuhan informasi menurut mereka masing-masing.

Dari ketujuh informan yang diwawancara mereka memiliki pemahaman yang sama mengenai kebutuhan informasi walaupun dengan cara penjelasan yang berbeda-beda. Satu hal yang dapat disimpulkan dari berbagai penjelasan mereka adalah bahwa kebutuhan informasi merupakan sesuatu yang harus dipenuhi dalam dirinya. Hal ini sesuai dengan pendapat yang dikemukakan oleh Wesig dan Belkin (dalam Pendit, 76) bahwa kebutuhan informasi adalah untuk mengisi kekosongan tertentu dalam diri manusia.

\section{Kebutuhan Informasi}

Menurut Doyle, bahwa kebutuhan informasi seseorang tentu akan berbeda-beda, hal ini banyak dipengaruhi oleh peran yang mereka jalani di dalam suatu kehidupan dan lingkungan mereka. Dalam penelitian ini peran yang diemban oleh mereka adalah sebagai fungsional Pustakawan di Universitas Padjadjaran.

Kemampuan komunikasi bagi pustakawan juga menjadi sangat penting. Pustakawan tidak hanya dituntut untuk dapat mengolah koleksi sampai siap pakai atau melayani peminjaman dan pengembalian koleksi. Pustakawan juga perlu dibekali dengan kemampuan berinteraksi dan berkomunikasi dengan baik. Selain itu kemampuan menelusur informasi juga harus didahului dengan komunikasi tanya jawab dengan pengguna agar jelas apa yang dibutuhkan oleh pengguna dan informasi apa saja yang relevan dengan kebutuhan mereka.

Dalam penelitian ini diketahui bahwa kebutuhan informasi informan banyak dipengaruhi oleh perannya sebagai pustakawan/tenaga perpustakaan khususnya di perguruan tinggi. Berkaitan dengan hal tersebut, seseorang dapat dikatakan melek informasi bila dalam memenuhi kebutuhan informasinya, mereka dapat menyesuaikan dengan peran yang dijalaninya (Doyle, 1992). Sehingga nantinya kebutuhan informasi tersebut dapat menunjang perannya sebagai pustakawan. Pustakawan yang mampu mengelola lembaga perpustakaan, mampu mengelola koleksi, mampu melayani kebutuhan informasi pengguna serta mengetahui apa kebutuhan informasi mereka.

\section{Identifikasi Kebutuhan Informasi}

Setelah seseorang sadar akan kebutuhan informasinya, seseorang yang melek informasi juga harus dapat mengidentifikasi kebutuhan informasinya. Dalam melakukan identifikasi kebutuhan informasi ada berbagai macam cara misalnya dengan penjabaran, membuat kerangka, bertanya pada sumber terdekat.

Dalam penelitian ini, terlihat bahwa masingmasing cara informan melakukan identifikasi kebutuhan informasi sesuai dengan apa yang dikemukakan oleh Hepworth yaitu dengan melakukan penjabaran (brainstorming). Selain itu menurut Proboyekti (2008), mengidentifikasi kebutuhan informasi dan untuk mengembangkan suatu topik dari berbagai aspek dapat juga dengan melakukan freewriting yaitu proses menuliskan apa saja yang ada dalam benak untuk mendapatkan ide topik yang selama ini menjadi minat, clustering yaitu membuat diagram hubungan antara istilah-istilah yang berkaitan satu sama lain, untuk menyusun ide-ide pembahasan dalam suatu karya penulisan, dramatizing menggunakan rumus lima $\mathrm{W}$ dan $1 \mathrm{H}$ (what, why, when, where, who, dan how). Jika topik sudah ditemukan maka hal-hal yang berkaitan dengan identifikasi masalah dapat lebih mudah ditemukan atau ditemukan.

\section{Penelusuran Informasi}

Dalam memenuhi kebutuhan informasi, seseorang akan berusaha mengakses informasi ke sumber-sumber informasi yang tersedia. Sumber informasi yang beragam mengharuskan setiap individu untuk dapat memilih sumber informasi yang tepat agar dapat memenuhi kebutuhan informasinya.

Mereka menggunakan alat bantu pencarian ini dikarenakan alasan terkenal dan merasa sudah terbiasa. Seseorang dapat dikatakan melek informasi bila ia dapat menggunakan alat bantu pencarian dengan pertimbangan atas pemahaman dan pengetahuan mereka mengenai search engine tersebut. Menurut ALA, pengetahuan mengenai search engine atau sistem temu kembali akan sangat membantu dalam menyusun strategi penelusuran atau pencarian yang efektif dan 
efisien. Hal ini dikarenakan setiap sistem database memiliki keunikan tersendiri.

Padahal untuk mendapatkan informasi yang dibutuhkan, dengan cepat dan tepat kita harus dapat mengetahui lebih banyak mengenai internet. Karena selain search engine google dan yahoo, masih banyak search engine lain (misalnya altavista, ask, dogpile, dll.) yang dapat dijadikan alat bantu. Ataupun misalnya kita ingin mencari jurnal ilmiah kita dapat memanfaatkan database $e$ journal. Tetapi pengetahuan informan mengenai dunia maya masih belum cukup karena pustakawan diharapkan dapat memberikan pelayanan yang optimal pada pengguna dalam melakukan penelusuran dan memenuhi kebutuhan informasi.

Hampir semua informan paling sering menggunakan alamat website yang terkait dengan bidang perpustakaan dan alamat pangkalan data $e$ jourrnal. Misalnya website dari PNRI dan blog Ilmu informasi dan perpustakaan: iperpin.wordpress.com. Selain itu, mereka juga sering menelusur informasi tentang koleksi dari OPAC pada situs perpustakaan lain untuk menelusur informasi yang dibutuhkan pengguna.

Selain untuk kepentingan pelayanan pada pengguna, mereka juga sering mengakses internet untuk keperluan hobi dan mencari pengetahuan umum lainnya. Misalnya mereka hampir setiap hari mengakses situs jejaring sosial facebook, yahoo messenger dan situs-situs berita seperti detik.com, kompas.com dan sebagainya.

Kendala yang sering mereka hadapi dalam mengakses internet untuk menelusur informasi di internet adalah tidak terbiasanya menggunakan strategi penelusuran khusus sehingga kadang informasi yang dicari agak sulit diperoleh. Padahal mereka sebetulnya sudah mendapat pengetahuan dan keterampilan tentang hal tersebut pada saat kuliah, khususnya di bidang perpustakaan. Kemudian hambatan lainnya adalah lemahnya koneksi internet di Unpad seperti bandwith yang minim, jaringan yang belum tertata dengan baik dan kinerja hardware komputer yang sering bermasalah karena serangan virus atau spesifikasi yang rendah.

Dari berbagai jawaban yang diberikan oleh informan, hampir semua memanfaatkan internet sebagai sumber informasi. Akan tetapi yang perlu diingat adalah sumber informasi yang dapat dieksplor bukan hanya internet. Seseorang yang melek informasi juga harus dapat memanfaatkan sumber-sumber lain sebagai sarana yang dapat dijadikan sumber untuk memenuhi berbagai kebutuhan informasi (Dobber, 2005 dalam Hanna, 2006).

\section{Strategi Penelusuran Informasi}

Perkembangan teknologi informasi menuntut seseorang untuk dapat lebih paham dalam penguasaan dan penggunaannya. Teknologi informasi banyak mempermudah kehidupan manusia untuk itu kita dituntut untuk dapat beradaptasi dengan perubahan zaman yang begitu cepat.

Berkaitan dengan perkembangan teknologi informasi, internet merupakan salah satu hal yang tidak dapat dilepaskan dari kehidupan. Namun berkembangnya internet harus disesuaikan dengan pemahaman mengenai internet dan kemampuan untuk dapat menggunakannya dengan baik seperti bagaimana cara penelusuran informasi melalui internet sehingga kita tidak terjebak dalam kubangan informasi yang tersedia di dalamnya.

Namuan pada kenyataannya, semua informan masih mengandalkan satu search engine yang sudah familiar dan kurang memahami cakupan dan pengetahuan yang cukup mengenai search engine tersebut. Dalam penelitian ini diketahui bahwa pemanfaatan internet sebagai sumber informasi masih belum didukung oleh pemahaman akan pentingnya melakukan penelusuran dengan strategi khusus. Informan masih sering menggunakan bahasa alamiah (natural language) atau kata kunci (keyword) dalam menerapkan strategi penelusuran di internet. Padahal seseorang dapat dikatakan literate terhadap informasi bila dalam melakukan penelusuran juga dapat mengaitkan istilah-istilah berhubungan dengan topik yang dicari.

Selain itu penggunaan teknik penelusuran juga diperlukan untuk mempermudah dan mempercepat proses penelusuran. Hal ini dapat dilakukan dengan menggunakan boolean operator (AND, OR, NOT) atau menggunakan pola tanda baca pada istilah subyek yang dicari. Dalam penelitian ini juga diketahui bahwa hampir semua informan belum menggunakan fungsi-fungsi tersebut, meskipun mereka sebetulnya mengetahuinya. Padahal seseorang dapat dikatakan information literate bila sudah menggunakan berbagai alat bantu dan teknik penelusuran informasi dalam berbagai jenis dan format (Alan Bundy 2004, 19). 


\section{Pemanfaatan Informasi}

Selain informasi dapat dilihat sebagai sesuatu yang relevan terhadap pembelajaran dan suatu pencapaian dalam pendidikan dan kehidupan, pemanfaatan informasi dapat dilihat sebagai bagian dari fondasi untuk dapat belajar sepanjang hayat.

Dalam kaitannya dengan kompetensi profesionalisme pustakawan, pemanfaatan informasi dapat dilakukan dalam beberapa hal sesuai dengan kebutuhan. Pustakawan berperan sebagai pelayan informasi, pengelola lembaga informasi, pengelola informasi, pembina minat baca masyarakat, pembina kesadaran masyarakat akan pentingnya informasi dan pengetahuan, subyek spesialis, penanggung jawab pengelolaan kekayaan intelektual masyarakat tentunya dapat memanfaatkan sebanyak mungkin informasi untuk dapat mendukung berjalannya peran tersebut.

Kemudian seorang pustakawan juga harus dapat mengembangkan profesionalismenya secara berkesinambungan dengan melakukan tindakan reflektif. Hal ini dilakukan dengan menilai kinerja diri sendiri secara terus menerus. Kemudian hasilnya dimanfaatkan untuk melakukan upayaupaya perbaikan dan peningkatan prosionalismenya tersebut. Tentunya juga pustakawan harus dapat terus mengikuti perkembangan yang ada dan terus belajar dari berbagai sumber dan cara.

Dalam hal ini informan juga sudah mulai melakukan diskusi dan interaksi dengan sesama pustakawan/praktisi perpustakaan khususnya pada tingkat perguruan tinggi seperti pada forum FPPTI dan IPI seperti pada saat dilakukannya pertemuan atau secara informal melalui media komunikasi yang digunakan.

Menurut standar Australian Framework, seseorang yang melek informasi mengaplikasikan informasi yang lama dengan apa yang didapatkan untuk membuat suatu konsep yang baru atau menciptakan satu pemahaman baru, dapat membandingkan dan menyatukan pemahaman baru dengan pengetahuan lama untuk menemukan satu nilai tambah dalam suatu informasi, kontradiksi, atau keunikan lain dari suatu informasi. Selain itu, dapat mengkomunikasikan pengetahuan dan pemahaman baru secara efektif.

\section{Mengkomunikasikan Informasi}

Dalam mengkomunikasikan informasi yang telah didapatkan, diharapkan tidak hanya terjadi kepada sesama pustakawan tetapi juga dapat meluas kepada pengguna perpustakaan dan masyarakat lainnya. Hal ini menjadi suatu tuntutan yang perlu dipenuhi mengingat peran pustakwan sebagai profesi yang juga mempunyai tanggung jawab terhadap masayarakat.

Selain itu, seseorang yang melek informasi juga harus dapat memilih media komunikasi dan format yang paling tepat untuk mendukung tujuan menyebarkan suatu produk informasi ke sasaran yang dituju dan menggunakan teknologi informasi yang cocok dalam menciptakan satu produk informasi. Semua informan melakukan komunikasi dengan pustakawan lain di Unpad dan biasanya dilakukan dalam bentuk formal dan informal. Secara formal, komunikasi yang dilakukan oleh informan adalah pada saat rapat. Sedangkan secara informal hampir dilakukan tiap hari melalui media komunikasi seperti email, chatting dan sebagainya. Hal-hal yang dibicarakan dalam pertemuan formal adalah menyangkut aktifitas kerja di perpustakaan. Sedangkan secara informal lebih banyak membicarakan hal-hal pribadi dan sharing tentang pengalaman masingmasing.

Komunikasi tidak hanya dapat dilakukan secara lisan dan tatap muka langsung, namun juga melalui tulisan dan secara tak langsung. Kegiatan komunikasi informal yang dilakukan oleh hampir semua informan lebih banyak dilakukan dalam bentuk tulisan yaitu melalui internet. Dalam hal ini, penggunaan e-mail, milis, yahoo messenger, facebook dan sebagainya merupakan bentuk komunikasi secara tertulis. Pustakawan tentunya harus dapat memanfatkan berbagai media komunikasi yang ada untuk berbagai kepentingan. Terutama untuk berinteraksi dengan pengguna dalam rangka memaksimalkan layanan pada pengguna. Hal ini sesuai dengan konsep library 2.0 yang saat ini sedang berkembang di dunia maupun di Indonesia. Konsep ini pertama kali dicetuskan oleh Michael Casey dalam Blog-nya LibraryCrunch pada tahun 2006. Library 2.0 sendiri didefinisikan sebagai sebuah kolaborasi antara berbagai aplikasi interaktif teknologi multimedia berbasis web pada layanan dan koleksi perpustakaan berbasis web (Manner dalam Foo, 2008). Nah, yang sangat berperan dalam penerapan konsep ini adalah pustakawan sebagai pengelola perpustakaan. Dalam penelitian ini, 
semua informan mengatakan bahwa mereka juga sering menggunakan berbagai aplikasi internet dan multimedia baik untuk kegiatan pelayanan pada pengguna maupun untuk kepentingan pribadi dalam rangka peningkatan wawasan dan pengatahuan mereka.

\section{Merencanakan Pemanfaatan Informasi}

Merencanakan pemanfaatan informasi di perpustakaan merupakan suatu upaya para pustakawan untuk dapat memenuhi kebutuhan informasi baik bagi dirinya maupun untuk para pengguna yang dilayaninya. Perencanaan ini dilakukan dengan menyesuaikan pada kebutuhan dan permintaan informasi tersebut. Melalui perencanaan ini diharapkan kebutuhan dan permintaan informasi terutama dari pengguna akan dapat terpenuhi secara efektif dan efisien.

\section{Evaluasi Pemanfaatan Informasi}

Pustakawan yang baik senantiasa melakukan evaluasi dan refleksi atas tugas pokok dan fungsi yang mereka jalani. Dengan evaluasi ini diharapkan mereka dapat terus memperbaiki peran dan tanggung jawabnya sebagai pustakawan. Evaluasi ini tidak harus selalu dilakukan oleh pihak lembaga/perpustakaan secara formal, namun hal itu dapat juga dilakukan secara individu oleh diri sendiri. Melalui evaluasi ini dapat diketahui apakah mereka sudah menjalankan perannya tersebut sebagai pustakawan dengan baik.

\section{Penerapan Literasi Informasi dalam Pelayanan Perpustakaan}

Dalam memberikan layanan perpustakaan yang optimal dan membimbing pengguna agar dapat menjadi individu yang mampu memanfaatkan perpustakaan dan sumber informasi lainnya secara mandiri agar mampu menjadi pembelajar sepanjang hayat (life long learner) adalah bukanlah hal yang mudah. Hal tersebut membutuhkan kemampuan pustakawan sebagai profesional yang dapat menjembatani proses belajar pengguna di perpustakaan. Untuk dapat mengetahui bagaimana informan menerapkan literasi informasi dalam aktifitasnya di perpustakaan adalah dengan mewawancarainya mengenai strategi dan metode pelayanannya di perpustakaan. Untuk dapat memperkuat jawaban informan, peneliti juga melakukan observasi dan pengamatan.
Berdasarkan pengamatan peneliti, bahwa semua informan selalu berusaha agar mereka mampu melayani pengguna dengan baik. Konsep literasi informasi yang mereka pahami dan mereka kuasai selalu coba mereka terapkan baik untuk kepentingan dirinya maupun untuk kepentingan pengguna yang dilayaninya dalam proses pelayanan di perpustakaan. Namun demikian, berbagai kendala juga sering mereka hadapi seperti kurang antusiasnya pengguna, waktu dan tenaga mereka yang terbatas dalam memberikan pelayanan pada pengguna, kurangnya perhatiannya lembaga atas kinerja dan upaya mereka dalam memberikan pelayanan. Selain itu keterbatasan fasilitas akses dan masih minimnya koleksi sumber informasi juga dirasakan cukup menghambat dalam penerapan konsep literasi informasi, khususnya di perpustakaan.

Kompetensi literasi informasi yang mereka kuasai merupakan hasil dari proses belajar dan peningkatan wawasan selama menjadi Pustakawan di Unpad. Ketika kuliah mereka sama sekali belum mengenal konsep ini karena literasi informasi merupakan keahlian baru yang diajarkan khususnya di program studi ilmu informasi dan perpustakaan. Di Jurusan Ilmu Informasi dan Perpustakaan Fikom Unpad sendiri mata kuliah literasi informasi baru diajarkan selama 3 tahun terakhir. Sedangkan informan yang pernah kuliah di program studi ilmu informasi dan perpustakaan semuanya merupakan angkatan tahun 90-an. Kompetensi literasi informasi yang mereka pelajari rata-rata diperoleh dari belajar melalui internet, mengikuti pertemuan-pertemuan ilmiah, mengikuti training/workshop dan ada juga yang hasil sharing pengetahuan dan wawasan dari rekan-rekan se-profesi di perguruan tinggi lain atau di lembaga lain.

\section{PENUTUP}

Hasil dari penelitian ini dapat disimpulkan bahwa kompetensi literasi informasi dapat menunjang profesionalisme dan aktifitas informan sebagai pustakawan. Hal ini dapat dilihat dari tiga aspek dalam melakukan aktifitas yang berhubungan dengan informasi yakni bagaimana menentukan kebutuhan informasi, penelusuran dan pencarian informasi serta bagaimana pemanfaatan informasi tersebut. Dari ketiga aspek tersebut peneliti berusaha mengungkapkan kompetensi literasi informasi para pustakawan di 
lingkungan Universitas Padjadjaran dengan hasil sebagai berikut:

Dalam menentukan kebutuhan informasi pustakawan di Unpad sudah tergolong baik. Mereka menentukan kebutuhan informasi sebagai upaya mengembangkan diri dalam menunjang kompetensi mereka sebagai fungsional pustakawan. Mereka sudah dapat memahami peran dan fungsi yang mereka jalani sebagai seorang pustakawan dan memiliki keinginan serta harapan untuk dapat terus meningkatkan kompetensi dan profesionalisme mereka dengan cara terus mengembangkan diri melalui berbagai cara dan upaya. Pengembangan diri yang dilakukan adalah dengan memenuhi kebutuhan informasi yang berhubungan dengan perannya sebagai pustakawan dari berbagai aspek.

Dalam melakukan pencarian informasi, para pustakawan di Universitas Padjadjaran masih dalam tingkat pengembangan. Akses terhadap informasi erat kaitannya dengan kemampuan dalam penggunaan teknologi informasi walaupun dengan cakupan yang berbeda. Dengan berkembangnya teknologi informasi yang begitu pesat, pustakawan di Universitas Padjadjaran sudah dapat menggunakan teknologi informasi yang ada walaupun belum secara maksimal.

Penelusuran informasi melalui internet masih dalam tahap pengembangan karena selama ini mereka hanya menggunakan fasilitas search engine yang menurut mereka familiar dan biasa digunakan. Bukan karena memahami dari fungsi search engine itu sendiri serta belum adanya upaya untuk mencari alternatif lain sebagai fasilitas mesin pencari. Hal ini membuktikan bahwa pustakawan yang ada di Universitas Padjadjaran belum dapat menguasai sepenuhnya kompetensi profesinya dalam rangka pemanfaatan teknologi informasi untuk pengembangan diri dan perannya sebagai ahli informasi.

Strategi penelusuran informasi yang diterapkan juga masih belum sistematis baik untuk kepentingan diri sendiri maupun untuk kepentingan ketika melayani pengguna di perpustakaan. Proses pencarian masih dilakukan secara sederhana tanpa menggunakan teknik penelusuran yang ideal. Walaupun mereka mengaku kadang selalu mendapatkan informasi yang dibutuhkan tetapi sistematika penelusuran masih belum dilakukan secara efektif dan efisien.

Pada dasarnya kemampuan untuk menggunakan informasi sudah tergolong baik.
Mereka sudah dapat menggabungkan pengetahuan yang dimiliki dan informasi yang mereka dapatkan untuk menjadi konsep pengetahuan yang baru. Hal ini dikarenakan latar belakang pendidikan mereka yang sudah cukup baik sehingga dapat melakukan perannya sebagai fungsional pustakawan dengan baik seperti melayani kebutuhan informasi pengguna, mengelola koleksi bahan pustaka, dan mengelola lembaga perpustakaanya secara umum.

Dalam melakukan perannya, pustakawan harus dapat memberikan pelayanan yang baik dan memuaskan, dapat membimbing pengguna agar dapat memanfaatkan informasi dan pengatahuan yang ada di perpustakaan serta memfasilitasi semua aktifitas pemanfaatan perpustakaan terutama dalam optimalisasi proses belajar, terlebih di tingkat perguruan tinggi. Untuk dapat seperti itu, maka perlu didukung oleh pihak universitas untuk dapat meningkatkan profesionalisme pustakawan, meningkatkan kinerja dan motivasi kerjanya, serta memperhatikan karirnya sebagai pustakawan.

Setelah melihat kemampuan literasi informasi para pustakawan di Universitas Padjadjaran yang penulis jadikan informan, dapat diketahui bahwa kemampuan yang mereka miliki dan mereka gunakan itu dapat menunjang profesionalismenya sebagai pustakawan. Meskipun kemampuan dari masing-masing informan berbeda satu dengan lainnya. Semestinya juga sebagai pustakawan harus sudah sangat ahli dalam menerapkan kompetensi literasi informasi tersebut. Apalagi pada program studi ilmu perpustakaan dan informasi sudah diajarkan sejak empat tahun terakhir, namun karena mereka kebanyakan lulusan tahun 90-a. Jadi mereka mempelajari dan mengetahui konsep ini hanya melalui pengalaman selama bekerja.

Walaupun belum dapat menerapkan konsep dan kompetensi literasi informasi secara mendalam, namun informan sudah dapat memanfaatkannya untuk kepentingan pengembangan dirinya dan untuk kelancaran aktifitas pelayanannya di perpustakaan. Mereka juga berupaya agar kemampuan yang dimilikinya itu dapat dimiliki dan digunakan juga oleh orang lain terutama pengguna di perpustakaannya. Hal tersebut mereka yakini sebagai bentuk upaya agar semua orang dapat memanfaatkan kemampuan literasi informasi ini sebagai bekal untuk dapat belajar sepanjang hayat dan bekal untuk siap dalam menghadapi hidup dan kehidupan di masa 
yang akan datang, terutama dalam menjalani kehidupan dalam masyarakat informasi.

Sejauh ini belum ada upaya serius dari pihak Universitas Padjadjaran maupun FakultasFakultas yang ada di dalamnya dalam memperhatikan nasib pustakawan. Malah yang sering terjadi adalah adanya semacam adanya upaya 'perkerdilan' peran dan fungsi pustakawan. Padahal kita semua tahu, bahwa Universitas Padjadjaran memiliki Program Studi Ilmu Informasi dan Perpustakaan. Namun pihak Universitas tidak melihat hal tersebut sebagai kekuatan dan modal dasar dalam mengembangkan perpustakaan dan kepustakawanan di perguruan tingginya. Jika Universitas Padjadjaran serius ingin mencapai visinya ke depan sebagai World Class University, maka pengembangan perpustakaan dan pustakawan dengan segala peran dan fungsinya adalah menjadi sebuah keniscayaan dan keharusan.

\section{DAFTAR PUSTAKA}

Amstrong, C, et al. 2005. CILIP defines

Information Literacy for the UK Library and Information update, 4 (1), 22-25. Diakses 08

Desember 2009, dari

http://www.cilip.org.uk/publications

lupdatemagazine/archive/archive2005/janfeb/ armstrong.htm

Bundy, Alan. (2004). Australian and New Zealand Information Literacy Framework : Principles, Standards and Practice. Diakses 19

Desember 2009, dari http://www.caul.edu.au/infoliteracy InfoliteracyFramework.pdf

Bungin, Burhan. (2007). Penelitian Kualitatif : Komunikasi, Ekonomi, Kebijakan Publik, Dan Ilmu Sosial Lainnya. Penerbit Kencana: Jakarta.

Doyle, CYSistina. (1992). Outcome Measures for Information Literacy Within the National Education Goals of 1990 : final report of the National Forum on Information Literacy. Summary of Findings. Washington, DC : US Department of Education. (ERIC document no; ED 351033). Diakses 19 Desember 2009 dari http://eric.ed.gov/ERICDocs/data/ericdocs2/c ontent_storage 01/0000000b/80/23/4a/12.pdf

Foo, Schubert. 2008. Library 2.0, Libraries and

Library School. Division of Information
Studies- Wee Kim Wee School of

Communication \& Information, Nanyang

Technological University. Diakses dari

http://www.ntu.edu.sg.

Hepworth, Mark. (1999). A Study of

Undergraduate Information Literacy and

Skills; The Inclusion of Information LiteracY and Skills in the Undergraduate Curriculum.

Diakses dari

www.ifla.org/IV/ifla65/papers/107-124e.htm$\underline{42 \mathrm{k}-}$

Koentjaraningrat. 1993. Metode Penelitian

Masyarakat. Jakarta: Gramedia.

Latuputty, Hanna. 2006. Information Literacy in Indonesia: A Challenge to Make a Brighter Future. Presentasi Seminar IPI ke-10.

Pendit, Putu Laxman. 2003. Penelitian Ilmu Perpustakaan dan Informasi: Sebuah Pengantar Diskusi Epistemologi \& Metodologi. Jakarta: JIP-FSUI 